\title{
Novel Task Specific Ionic Liquids to Remove Heavy Metals from Aqueous Effluents
}

\author{
Pape Diaba Diabate ${ }^{1}$, Laurent Dupont ${ }^{1,2, *}$, Stéphanie Boudesocque ${ }^{1,2}$ and \\ Aminou Mohamadou 1,2 \\ 1 Institut de Chimie Moléculaire de Reims (ICMR), Université de Reims Champagne-Ardenne, \\ CNRS UMR 7312, UFR des Sciences Exactes et Naturelles, Bâtiment 18 Europol'Agro, BP 1039, \\ F-51687 Reims CEDEX 2, France; pape-diaba.diabate@univ-reims.fr (P.D.D.); \\ stephanie.boudesocque@univ-reims.fr (S.B.); aminou.mohamadou@univ-reims.fr (A.M.) \\ 2 French Network of Hydrometallurgy Promethee, GDR CNRS 3749, 2 Rue du Doyen Roubault, \\ 54518 Vandoeuvre-lès-Nancy CEDEX, France \\ * Correspondence: laurent.dupont@univ-reims.fr; Tel.: +33-3-2691-3336
}

Received: 10 May 2018; Accepted: 29 May 2018; Published: 2 June 2018

\begin{abstract}
Task Specific Ionic Liquids (ILs) were generated by association between a cationic ester derivative of betaine and coordinating inorganic anions such as dicyanamide (Dca ${ }^{-}$), chlorosalycilate (ClSal) and saccharinate (sac). Extraction of $\mathrm{Cu}$ (II), $\mathrm{Ni}$ (II), Co.(II), $\mathrm{Pb}$ (II) and Cd(II) from water was performed with these ILs at room temperature. Our results show that ionic liquid with Clsal anions have a high extraction efficiency towards $\mathrm{Cu}(\mathrm{II}), \mathrm{Ni}(\mathrm{II}), \mathrm{Cd}(\mathrm{II})$, and $\mathrm{Pb}$ (II), whereas dicyanamide ionic liquid may extract efficiently $\mathrm{Cu}(\mathrm{II}), \mathrm{Ni}$ (II) Co.(II) and $\mathrm{Cd}(\mathrm{II})$. Ionic liquids with saccharinate anions are selective of $\mathrm{Cd}(\mathrm{II})$ ions. The extraction mechanism has been studied by the determination of the coextraction of the counter ion of the metal salt. Our results show that the extraction mechanism proceeds via a mixed process involving both cation exchange and ion-pairing. The proportion of which depends on the nature of the cation. The coordination of $\mathrm{Cu}(\mathrm{II})$, $\mathrm{Ni}$ (II) and Co.(II) in ionic liquid phase was followed by UV-vis spectroscopies. The metal could be back-extracted from the ionic liquid phase with aqueous EDTA solutions. The metal extractability of the ionic liquid after the back-extraction is equivalent to that of the fresh mixture showing that ionic liquid can be reused for several extraction and back-extraction cycles.
\end{abstract}

Keywords: ionic liquids; metal extraction; liquid-liquid extraction; back-extraction; reusability

\section{Introduction}

The rapid growth of industrial activities in recent years has led to a significant increase in the volume and toxicity of industrial effluents containing heavy metals. Heavy metals have a significant toxicity towards humans and the environment [1], whence the profusion of regulations governing the treatment and removal of heavy metals from industrial effluents.

Pollution reduction will, in the future, generate economic profits, because of the continuous increase in the value of metals [2]. The elimination of metals from industrial effluents may be achieved by technologies such as chemical precipitation, coagulation, solvent extraction, electrolysis, membrane separation, ion-exchange, and adsorption [3,4]. Among them, liquid-liquid extraction is one of the most performing technologies for the recovery of metal ions, from industrial wastewaters. This technology uses extracting agents and organic solvents (kerosene, toluene, etc.) as diluent. The loss of organic diluent via volatilization, during extraction processing, generates negative environmental impact and may cause serious damage on human health. Consequently, "greener" extraction methods are being sought, and the use of ionic liquids (ILs) constitutes a possible alternative for the replacement 
of traditional organic solvent [5]. In the last decade, significant works have shown that Room Temperature Ionic Liquids (RTILs) are potential substitutes for traditional solvents in liquid-liquid extraction processes, for the separation of metal ions [6-9]. Another specific advantage of ILs concerns the possibility of metal recovery by electrodeposition [10]. However, the conventional ionic liquids have a limited efficiency for metal extraction. The use of Task-Specific Ionic Liquids (TSIL) [11-19] by functionalizing organic cation with chelating moieties to increase the affinity of metals for the IL phase may overcome this problem. Ionic liquids with a coordinating anion represent another strategy to increase the recovery of metals by the IL phase. ILs with fluorinated acetylacetonate ligands have shown interesting effectiveness for the extraction of $\mathrm{Eu}(\mathrm{III}), \mathrm{Nd}(\mathrm{III})$, and Co. (II) $[20,21]$. The development of "green" extraction processes with IL requires a knowledge of the mechanisms involved, for the transfer of ions between IL and the aqueous phase, to privilege the use of ionic liquids limiting the ionic exchanges between the aqueous and organic phases [22-26]. Here, we report the ability of task-specific ionic liquids to remove heavy metals from water. The quaternary ammonium cations derivative of betaine $\left\{\operatorname{tri}\left(n\right.\right.$-butyl)(-ethoxy-2-oxoalkyl)ammonium $\left.\left(\mathrm{BuNC}_{\mathrm{n}}{ }^{+}\right)\right\}$ were associated to non-fluorinated coordinating anion such as sacharinate $\left(\mathrm{Sac}=\mathrm{C}_{7} \mathrm{H}_{4} \mathrm{NO}_{3} \mathrm{~S}^{-}\right.$), chlorosalicylate $\left(\mathrm{ClSal}=\mathrm{C}_{7} \mathrm{H}_{5} \mathrm{O}_{3}{ }^{-}\right)$and dicyanamide $\left(\mathrm{Dca}=\mathrm{C}_{2} \mathrm{~N}_{3}{ }^{-}\right)$to generate hydrophobic ionic liquids (Figure 1), use as pure extracting phase $[13,27,28]$. The potential of ILs with chelating anions, as extracting agents, was investigated towards divalent toxic metals $\mathrm{Cu}(\mathrm{II}), \mathrm{Cd}(\mathrm{II}), \mathrm{Ni}(\mathrm{II}), \mathrm{Co}$.(II) and $\mathrm{Pb}$ (II). The choice of the betaine derivative is justified by its accessibility via simple synthetic route, by its availability, the cost of starting materials, and its structural modularity, which allows the control of the hydrophobicity of cation by varying the alkyl chain length bound to the ammonium group. The choice of anions is dictated by their hydrophobic and chelating nature. The sacharinate and chlorosalicylate anions $[29,30]$ are known for their complexing capacity towards heavy and first row transition metals, respectively. The dicyanamide anion is a cheap anion that is easy to handle to generate ILs. Its chelating ability for metal ions is well known $[31,32]$ and the ability of the $\mathrm{Dca}^{-}$ionic liquids to extract $\mathrm{Cu}(\mathrm{II})$ and $\mathrm{Ni}(\mathrm{II})$ from water $[26,33,34]$ was shown in a previous study.

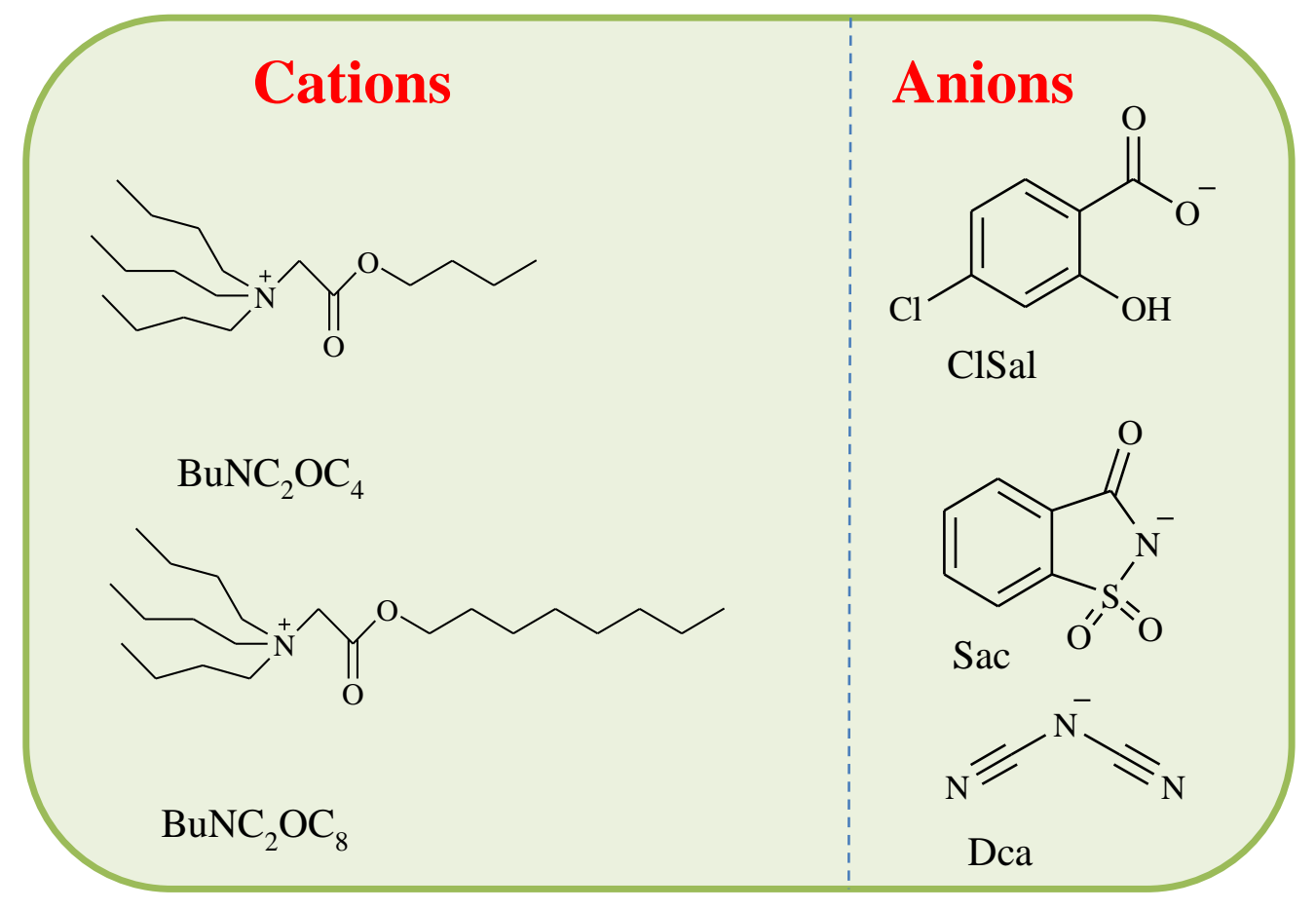

Figure 1. Structure of different analogues of glycine betaine based ionic liquids used in this study. 


\section{Experimental Section}

\subsection{Chemicals and Reagents}

All chemical and reagents used in this study were used as received without further purification. Sodium nitrate $(99 \%)$ sodium chloride $(99 \%)$, sodium dicyanamide $(99 \%)$, Tri $(n$-butyl)amine $(99 \%)$, 1-butanol (99\%) and ethyl bromoacetate (98\%) were obtained from Sigma-Aldrich (Diegem, Belgium). Ethylenediaminetetraacetic acid disodium salt dihydrate (99\%), methanesulfonic acid (99\%), 1-octanol (99\%), sodium saccharinate (99\%) and 4-chlorosalicylic acid $(99 \%)$ was purchased by Acros (Illkirsh, France).

The solutions of metals were prepared by dissolving their corresponding nitrate salt (analytical grade purchased from Sigma-Aldrich (Saint Quentin-Fallavier, France)-Fluka Chemical (Bucharest, Romania,) in double distilled and deionized water.

\subsection{Analytical Measurements}

Elemental analyses (C, H, and N) were carried out on a Perkin-Elmer $2400 \mathrm{C}, \mathrm{H}, \mathrm{N}$ element analyzer in our university. The UV-visible spectra of metal solutions were recorded using a Carry-5000 Varian spectrophotometer. Routine ${ }^{1} \mathrm{H}$ NMR spectra were recorded in deuterated dimethyl sulfoxide $\mathrm{C}_{2} \mathrm{D}_{6} \mathrm{OS}$ at room temperature with a Bruker AC 250 spectrometer. Chemical shifts (in ppm) for ${ }^{1} \mathrm{H}$ NMR spectra were referenced to residual protic solvent peaks. The metal analyses were performed by UV-vis spectroscopy using EDTA for $\mathrm{Cu}$ (II) and Ni(II) and by ICP-OES, Thermo Fisher ICAP Series for $\mathrm{Cd}$ (II) and $\mathrm{Pb}$ (II). The concentrations of $\mathrm{NO}_{3}{ }^{-}$ions in aqueous solution before and after extraction were determined by ion-HPLC with a Metrohm with a conductivity detector.

\subsection{Extraction Experiments}

Metals nitrate aqueous solutions were prepared in deionized water. Metal ions distribution ratios were determined by mixing $0.5 \mathrm{~g}$ of IL and $2 \mathrm{~mL}$ of aqueous phase. The mixture was shaken for $24 \mathrm{~h}$ to reach equilibrium and then centrifuged at $2000 \mathrm{rpm}$ for $5 \mathrm{~min}$. The separated organic and aqueous phases, both clear and transparent, were then separated for analysis. The aqueous phase composition was analyzed by spectrophotometry UV-vis or by ICP-OES. The metal ion concentration in the IL phase was deduced from the difference between the concentration of metal ions in the aqueous phase before and after extraction. The efficiency of the extraction process was evaluated by calculation of the extraction percentage $(\% E)$ using the following equation:

$$
E=100 * \frac{\left(C_{i n}-C_{f i n}\right)}{C_{i n}}
$$

where $C_{\text {in }}\left(\mathrm{mol} \mathrm{L}^{-1}\right)$ is the concentration in the initial aqueous solution and $C_{\text {fin }}\left(\mathrm{mol} \mathrm{L}^{-1}\right)$ is the concentration in the final aqueous solution. The metal extraction percentages $(\% \mathrm{E})$ were determined at $25^{\circ} \mathrm{C}$. The initial concentration of metal solutions is fixed at $5 \times 10^{-2} \mathrm{~mol} \mathrm{~L}^{-1}$. The experiments were made in triplicate to ensure the reproducibility of the assay, and the mean values of extraction yields were considered for each system studied. The distribution ratio $(D)$ is calculated using the following formula:

$$
D=\frac{\left(C_{i n}-C_{f i n}\right)}{C_{f i n}} \frac{V_{w}}{V_{I L}}
$$

$V_{w}$ and $V_{I L}$ correspond to the volume of water and ionic liquid phases, respectively. The maximum $D$ value measurable in this study is assumed to be $5 \times 10^{2}$. The relative uncertainty on $D$ is $\pm 10 \%$. Experimental results done in duplicate agree within $5 \%$. 
In back-extraction experiments, the IL phase with metal extracted was contacted with $2 \mathrm{~mL}$ of aqueous disodique EDTA solution $\left(\mathrm{C}=10^{-1} \mathrm{~mol} \cdot \mathrm{L}^{-1}\right.$ of $\left.\mathrm{Na}_{2} \mathrm{H}_{2} \mathrm{Y}\right)$ during $4 \mathrm{~h}$ under stirring. The percentage of metal back extracted has been determined from the analysis of aqueous phase.

\section{Results and Discussion}

The preparation of different ILs was carried out by three main steps: the first step is the preparation of bromide precursor $\left(\mathrm{BuNC}_{2} \mathrm{OC}_{2}-\mathrm{Br}\right)$ and the second step is the preparation of the cationic ester derivative of betaine by transesterification of $\mathrm{BuNC}_{2} \mathrm{OC}_{2}-\mathrm{Br}$ with butanol or octanol. The third step is the anionic metathesis reaction to generate hydrophobic ILs. The synthetic pathway is given in Figure 2.
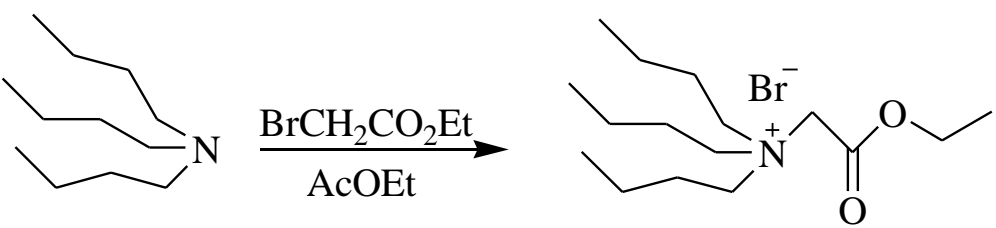
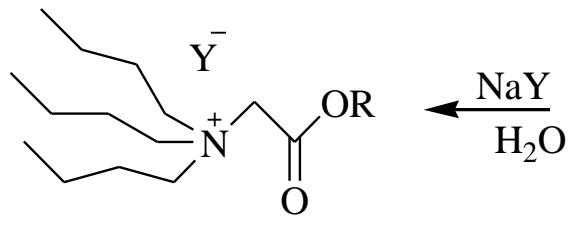

$\mathrm{Y}=\mathrm{Sac}, \mathrm{ClSal}$ or Dca

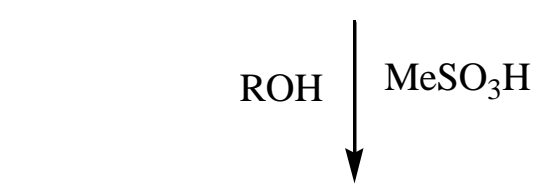

Figure 2. Synthetic route of hydrophobic ionic liquids.

The preparation of bromide salt can be considered as the least difficult step; this reaction is performed in mild conditions. The bromide salt powder was recovered through simple filtration with a quantitatively yield.

In the second step, the strategy used for the esterification reaction is to perform the reaction without any additional solvent; alcohol was also considered as solvent. Methanesulfonic acid was selected as reaction catalyst. It is the best candidate for a green synthesis route, often recyclable and less aggressive than conventional acids [35]. Anionic metathesis between the ester formed and sodium saccharinate, sodium dicyanamide and sodium chlorosalicylate is carried out in water and led in all cases to the formation of hydrophobic ILs with a good yield $(>78 \%)$. All the ILs are viscous liquids at room temperature.

ILs with saccharinate and chlorosalicylate anions are slightly denser than water with values ranging from 1.040 to $1.111 \mathrm{~g} \cdot \mathrm{mL}^{-1}$ at $25{ }^{\circ} \mathrm{C}$ (Table 1), whereas ILs with dicyanamide anion have the density less than unity. All the ionic liquids with $\mathrm{BuNC}_{2} \mathrm{OC}_{4}{ }^{+}$cations are denser than those of $\mathrm{BuNC}_{2} \mathrm{OC}_{8}{ }^{+}$cations.

At room temperature, all ionic liquids form two liquid phases when contacted with water. In biphasic system, water is the upper phase with sacharinate and chlorosalicylate based ionic liquids, and the lower phase with dicyanamide ionic liquids. 
Table 1. Room temperature ionic liquids density at $25^{\circ} \mathrm{C}$.

\begin{tabular}{cc}
\hline Ionic Liquid & Density $\left(\mathrm{g} \cdot \mathbf{m L}^{-\mathbf{1}}\right)$ \\
\hline $\mathrm{BuNC}_{2} \mathrm{OC}_{4}-\mathrm{Sac}$ & 1.11 \\
$\mathrm{BuNC}_{2} \mathrm{OC}_{8}-\mathrm{Sac}$ & 1.04 \\
$\mathrm{BuNC}_{2} \mathrm{OC}_{4}-\mathrm{ClSal}$ & 1.10 \\
$\mathrm{BuNC}_{2} \mathrm{OC}_{8}-\mathrm{ClSal}$ & 1.02 \\
$\mathrm{BuNC}_{2} \mathrm{OC}_{4}$-Dca & 0.96 \\
$\mathrm{BuNC}_{2} \mathrm{OC}_{8}$-Dca & 0.96 \\
\hline
\end{tabular}

The solubility of the ionic liquids in water were measured by NMR for dicyanamide based ionic liquids, or spectrophotometry UV-vis for chlorosalicylate or saccharinate based ionic liquid. The solubility of $\mathrm{BuNC}_{2} \mathrm{OC}_{4}$-Clsal and $\mathrm{BuNC}_{2} \mathrm{OC}_{8}$-Clsal are equal to 0.3 and $0.005 \%$, respectively and are comparable with those of $\mathrm{BuNC}_{2} \mathrm{OC}_{4}$-Dca and $\mathrm{BuNC}_{2} \mathrm{OC}_{8}$-Dca equal to 0.35 and $0.26 \%$, respectively. Ionic liquids with saccharinate anion are more soluble than those with dicyanamide and chlorosalycilate anions with the percentage values of $2.85\left(\mathrm{BuNC}_{2} \mathrm{OC}_{4}\right.$-Sac) and $1.24 \%\left(\mathrm{BuNC}_{2} \mathrm{OC}_{8}\right.$-Sac), respectively.

\subsection{Extraction of $\mathrm{Cu}(\mathrm{II}), \mathrm{Ni}(\mathrm{II}), \mathrm{Cd}(\mathrm{II}), \mathrm{Co}$.(II) and $\mathrm{Pb}(\mathrm{II})$ from Aqueous Solutions}

We compare the extraction properties of six ionic liquids with a complexing anion, towards a panel of five metal cations, $\mathrm{Cu}$ (II), $\mathrm{Ni}$ (II), $\mathrm{Cd}$ (II), $\mathrm{Co}$.(II) and $\mathrm{Pb}$ (II). These cations are chosen for their presence in industrial discharges.

The percentage of extraction $(\% \mathrm{E})$ is determined with solutions of the nitrate salts of each metal at $0.05 \mathrm{~mol} \cdot \mathrm{L}^{-1}$ and at $25^{\circ} \mathrm{C}$. The extraction yields $(\% \mathrm{E})$ for each IL are depicted in Figure 3 . The corresponding distribution ratio are given in Table 2.

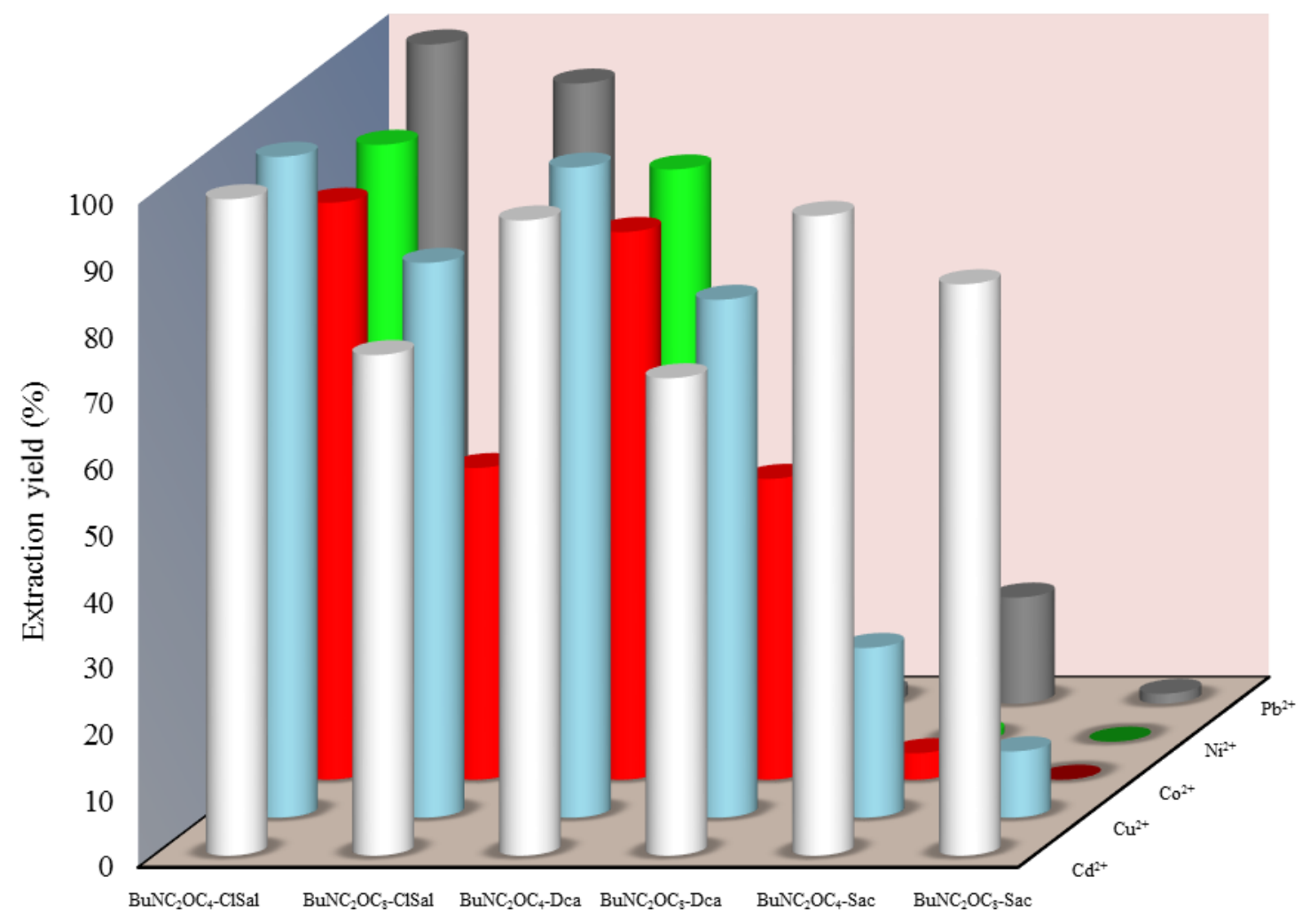

Figure 3. Extraction yields $(\% \mathrm{E})$ for metal aqueous nitrate salt with $\mathrm{BuNC}_{2} \mathrm{OC}_{4}$ (C8)-Sac, $\mathrm{BuNC}_{2} \mathrm{OC}_{4}(\mathrm{C} 8)-\mathrm{Clsal}$ and $\mathrm{BuNC}_{2} \mathrm{OC}_{4}(\mathrm{C} 8)$-Dca. $\mathrm{C}_{\text {metal }}=0.05 \mathrm{~mol} \mathrm{~L}{ }^{-1} ; \mathrm{V}_{\mathrm{w}}=2 \mathrm{~mL} ; \mathrm{m}_{\mathrm{Il}}=0.5 \mathrm{~g}$. 


\subsection{Influence of the Anion of the Ionic Liquid}

The overall examination of Figure 3 shows that the most efficient anion for the extraction of metals is the ClSal anion. Indeed, for all metallic cations, extraction yields are higher than $75 \%$ with $\mathrm{BuNC}_{2} \mathrm{OC}_{4}$-ClSal. By comparison, $\mathrm{BuNC}_{2} \mathrm{OC}_{4}$-Dca shows slightly weaker extraction yield, and $\mathrm{BuNC}_{2} \mathrm{OC}_{4}$-sac shows interesting extraction properties only towards $\mathrm{Cd}(\mathrm{II})$. The influence of the anion is more pronounced with ionic liquids containing $\mathrm{BuNC}_{2} \mathrm{OC}_{8}$ cation. Indeed, $\mathrm{BuNC}_{2} \mathrm{OC}_{8}$-ClSal and $\mathrm{BuNC}_{2} \mathrm{OC}_{8}$-Dca exhibit similar extraction yield with $\mathrm{Cu}$ (II), $\mathrm{Cd}$ (II) and $\mathrm{Co}$.(II), but the extraction of $\mathrm{Ni}(\mathrm{II})$ does not exceed a few percent with $\mathrm{BuNC}_{2} \mathrm{OC}_{8}$-Dca, while it is close to $50 \%$ with $\mathrm{BuNC}_{2} \mathrm{OC}_{8}$-Clsal. Moreover, $\mathrm{Pb}(\mathrm{II})$ is totally extracted with $\mathrm{BuNC}_{2} \mathrm{OC}_{8}$-Clsal, whereas the extraction does not exceed a few percent with $\mathrm{BuNC}_{2} \mathrm{OC}_{8}$-Dca.

Table 2. Distribution ratio $(D)$ for metal aqueous nitrate salt with $\mathrm{BuNC}_{2} \mathrm{OC}_{4}\left(\mathrm{C}_{8}\right)-\mathrm{Sac}$, $\mathrm{BuNC}_{2} \mathrm{OC}_{4}\left(\mathrm{C}_{8}\right)-\mathrm{ClSal}$ and $\mathrm{BuNC}_{2} \mathrm{OC}_{4}\left(\mathrm{C}_{8}\right)$-Dca; $\mathrm{C}_{\text {metal }}=0.05 \mathrm{~mol} \mathrm{~L}^{-1} ; \mathrm{V}_{\mathrm{w}}=2 \mathrm{~mL} ; \mathrm{m}_{\mathrm{Il}}=0.5 \mathrm{~g}$.

\begin{tabular}{lccccc}
\hline Ionic Liquid & $\mathbf{C u}(\mathrm{II})$ & $\mathbf{C d}(\mathrm{II})$ & $\mathbf{P b}(\mathrm{II})$ & $\mathbf{N i ( I I )}$ & $\mathbf{C o . ( I I )}$ \\
\hline $\mathrm{BuNC}_{2} \mathrm{OC}_{4}-\mathrm{Sac}$ & 1.5 & 120.0 & 0.8 & 0.1 & 0.2 \\
$\mathrm{BuNC}_{2} \mathrm{OC}_{8}$-Sac & 0.4 & 25.4 & 0.1 & - & - \\
$\mathrm{BuNC}_{2} \mathrm{OC}_{4}$-ClSal & 1301.4 & 439.6 & 735.6 & 40.0 & 29.7 \\
$\mathrm{BuNC}_{2} \mathrm{OC}_{8}$-ClSal & 21.30 & 12.8 & 59.9 & 4.5 & 3.7 \\
$\mathrm{BuNC}_{2} \mathrm{OC}_{4}$-Dca & 192.5 & 178.5 & 0.1 & 24.1 & 18.1 \\
$\mathrm{BuNC}_{2} \mathrm{OC}_{8}$-Dca & 13.7 & 1.8 & 0.1 & 0.3 & 3.2 \\
\hline
\end{tabular}

The results reported in Figure 3 and in Table 2 show that the capability of ionic liquids to extract a metal ion is greatly correlated to the ability of the anion of the ionic liquid, to form stable complexes with the metal cation. The extraction of first row transition metal (Cu(II), Co.(II), Ni(II)) by Dca or ClSal based ionic liquids show that the affinity of the metal ions for ionic liquid phase is weak for $\mathrm{Ni}(\mathrm{II})$ and $\mathrm{Co}$.(II) and higher for $\mathrm{Cu}$ (II). Such a trend may be related to the formation constants of complexes of these metals with the anions of the ionic liquids.

This assumption is corroborated by the values of the stability constants of $\mathrm{M}(\mathrm{II})$-salicylate complexes for $\mathrm{Cu}$ (II), $\mathrm{Ni}$ (II) and $\mathrm{Co}$.(II). The salicylate moieties may form stable relatively complexes by bidentate coordination giving a five membered rings species with metal ions. The first stability constant of $\mathrm{M}(\mathrm{II})$-salycilate complexes $\left(\log \beta_{1}\right)$ for $\mathrm{Ni}$ (II) and Co.(II) are 8.65 and 8.09 , respectively. This reflects a similar affinity of these two metals for the salicylate anion $[31,36]$. The higher extraction yields of $\mathrm{Cu}(\mathrm{II})$ compared to $\mathrm{Ni}$ (II) and $\mathrm{Co}$.(II) is in agreement with a higher stability constant for $\mathrm{Cu}$ (II) with a $\log \beta_{1}$ of 10.65 [31]. The high extraction yields of heavy metals $(\mathrm{Cd}(\mathrm{II})$ and $\mathrm{Pb}(\mathrm{II}))$ by $\mathrm{ClSal}$ based ionic liquids are equally in relation with the high stability constants of salicylate- $\mathrm{Cd}(\mathrm{II})$ (or $\mathrm{Pb}$ (II)) complexes [36,37]. The selectivity factor (SF) which represents the ratio between the distribution ratio of two metals for a given ionic liquid, indicates the selectivity of the ionic liquid towards the two metals gives useful information about the efficiency of the separation. The selectivity factors of $\mathrm{Cu}$ (II) towards $\mathrm{Ni}$ (II) $\left(\mathrm{SF}_{\mathrm{Cu} / \mathrm{Ni}}\right)$ or $\mathrm{Co}$.(II) $\left(\mathrm{SF}_{\mathrm{Cu} / \mathrm{Co}}\right.$.) for $\mathrm{BuNC}_{2} \mathrm{OC}_{4}-\mathrm{ClSal}$ are between 30 and 50, respectively, whereas for $\mathrm{BuNC}_{2} \mathrm{OC}_{8}-\mathrm{ClSal}$ it is only between four and six, respectively. It seems that $\mathrm{BuNC}_{2} \mathrm{OC}_{4}$ - $\mathrm{ClSal}$ is more selective than $\mathrm{BuNC}_{2} \mathrm{OC}_{8}$-ClSal for the separation of the first row transition metals.

The coordination of metal in the IL phases was investigated on the basis of the spectrophotometric analysis of the ionic liquid phase after extraction of $\mathrm{Co}$.(II), $\mathrm{Cu}(\mathrm{II})$ and $\mathrm{Ni}(\mathrm{II})$. The electronic spectra of $\mathrm{Ni}(\mathrm{II})$ in $\mathrm{BuNC}_{2} \mathrm{OC}_{8}-\mathrm{ClSal}$ are characteristic to $\mathrm{Ni}$ (II) in an octahedral environment (Figure 4). The two bands with the $\lambda_{\max }$ located at 1145 and $700 \mathrm{~nm}$ are assigned to the ${ }^{3} \mathrm{~A}_{2} \mathrm{~g} \rightarrow{ }^{3} \mathrm{~T}_{2} \mathrm{~g}$ and ${ }^{3} \mathrm{~A}_{2} \mathrm{~g} \rightarrow{ }^{3} \mathrm{~T}_{1} \mathrm{~g}(\mathrm{~F})$ transitions, respectively [38]. A third band with the $\lambda_{\max }$ located around $400 \mathrm{~nm}$ and partially masked by an intense transfer charge band is attributed to a ${ }^{3} \mathrm{~A}_{2} \mathrm{~g} \rightarrow{ }^{3} \mathrm{~T}_{1} \mathrm{~g}(\mathrm{P})$ transitions. The spectrum is shifted to weaker energy by comparison to the spectrum of $\mathrm{Ni}\left(\mathrm{H}_{2} \mathrm{O}\right)_{6}{ }^{2+}$ in aqueous solutions. This evidences the coordination of $\mathrm{Ni}(\mathrm{II})$ by oxygen atoms of the ClSal anion. 


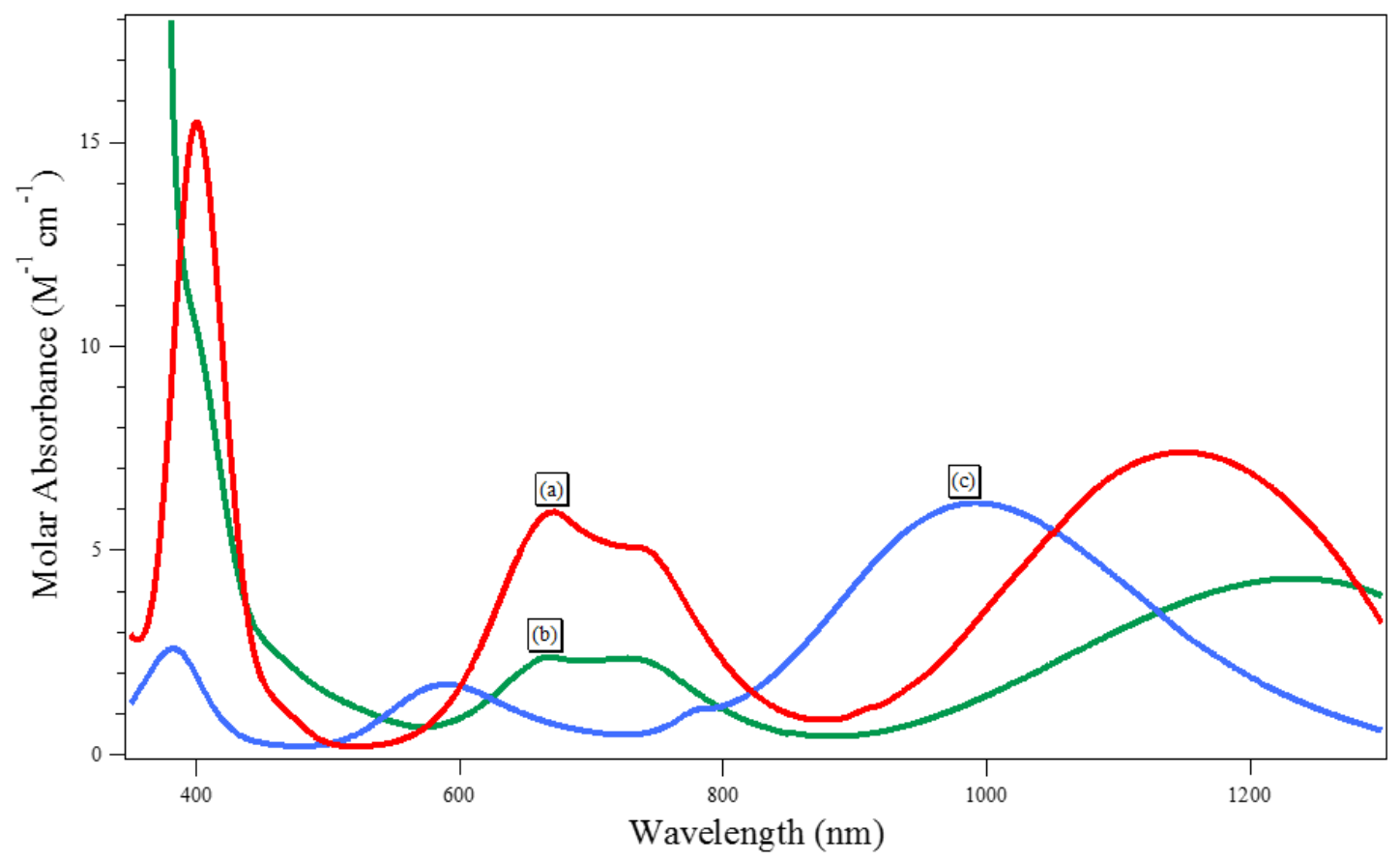

Figure 4. UV-Vis spectra of $\mathrm{Ni}\left(\mathrm{NO}_{3}\right)_{2}$ in ILs (a) $\mathrm{BuNC}_{2} \mathrm{OC}_{4}$-ClSal phase; (b) $\mathrm{BuNC}_{2} \mathrm{OC}_{4}$-Dca and (c) aqueous phase. $\mathrm{C}_{\text {metal }}=0.05 \mathrm{~mol} \mathrm{~L}^{-1} ; \mathrm{V}_{\mathrm{w}}=2 \mathrm{~mL} ; \mathrm{m}_{\mathrm{Il}}=0.5 \mathrm{~g} ; \mathrm{UV}$-vis spectra are recorded in ethylacetate for ionic liquid (IL) phase.

UV-visible spectra of $\mathrm{Cu}(\mathrm{II})$ in IL phases are depicted Figure 5. The spectrum of $\mathrm{BuNC}_{2} \mathrm{OC}_{8}-\mathrm{ClSal}$ after extraction of copper shows one single $\mathrm{d}-\mathrm{d}$ transition in the visible region with a maximum wavelength at $745 \mathrm{~nm}$. The relatively broad shape of the band and the value of molar extinction coefficient would be indicative of an octahedral copper complex. The higher molar absorbance of $\mathrm{Cu}(\mathrm{II})$ in IL phase indicates that the $\mathrm{Cu}(\mathrm{II})$ complex is more distorted than the $\mathrm{Cu}\left(\mathrm{H}_{2} \mathrm{O}\right)_{6}{ }^{2+}$ species.

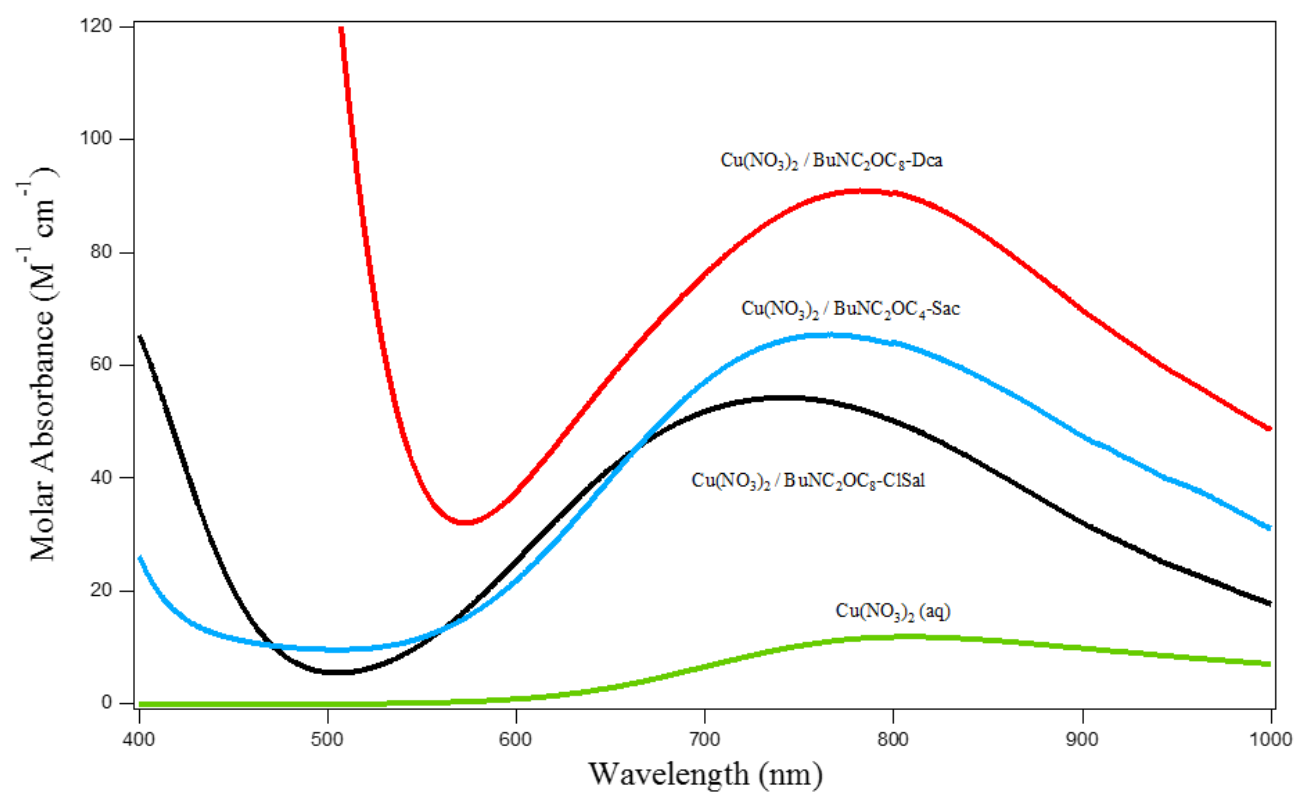

Figure 5. UV-Vis spectra of $\mathrm{Cu}\left(\mathrm{NO}_{3}\right)_{2}$ in aqueous and in ionic liquid phase. $\mathrm{C}_{\text {metal }}=0.05 \mathrm{~mol} \mathrm{~L}{ }^{-1}$; $\mathrm{V}_{\mathrm{w}}=2 \mathrm{~mL} ; \mathrm{m}_{\mathrm{Il}}=0.5 \mathrm{~g}$; UV-vis spectra are recorded in ethylacetate for IL phase. 
Figure 6 represents the spectra of $\mathrm{Co}^{2+}$ in the different IL phases. The spectrum of Co.(II) in $\mathrm{BuNC}_{2} \mathrm{OC}_{8}$-ClSal shows in the visible region, similar features than the spectrum of $\mathrm{Co} .\left(\mathrm{NO}_{3}\right)_{2}$ in aqueous phase, with a band at $530 \mathrm{~nm}$ and with a shoulder at $480 \mathrm{~nm}$. This band as well as its shoulder correspond to the two following transitions ${ }^{4} \mathrm{~T}_{1} \mathrm{~g}(\mathrm{~F}) \rightarrow{ }^{4} \mathrm{~A}_{2} \mathrm{~g}(\mathrm{~F})$ and ${ }^{4} \mathrm{~T}_{1} \mathrm{~g}(\mathrm{~F}) \rightarrow{ }^{4} \mathrm{~T}_{1} \mathrm{~g}(\mathrm{P})$. The molar absorption coefficient of IL phase at $530 \mathrm{~nm}$ is equal to $33 \mathrm{~cm} \mathrm{~mol}^{-1} 1$. All these features are indicative of a Co.(II) in octahedral environment. It is interesting to note that the spectrum of Co.(II)) in $\mathrm{BuNC}_{2} \mathrm{OC}_{8}-\mathrm{ClSal}$ is shifted towards lower energy compared to those recorded in aqueous media.

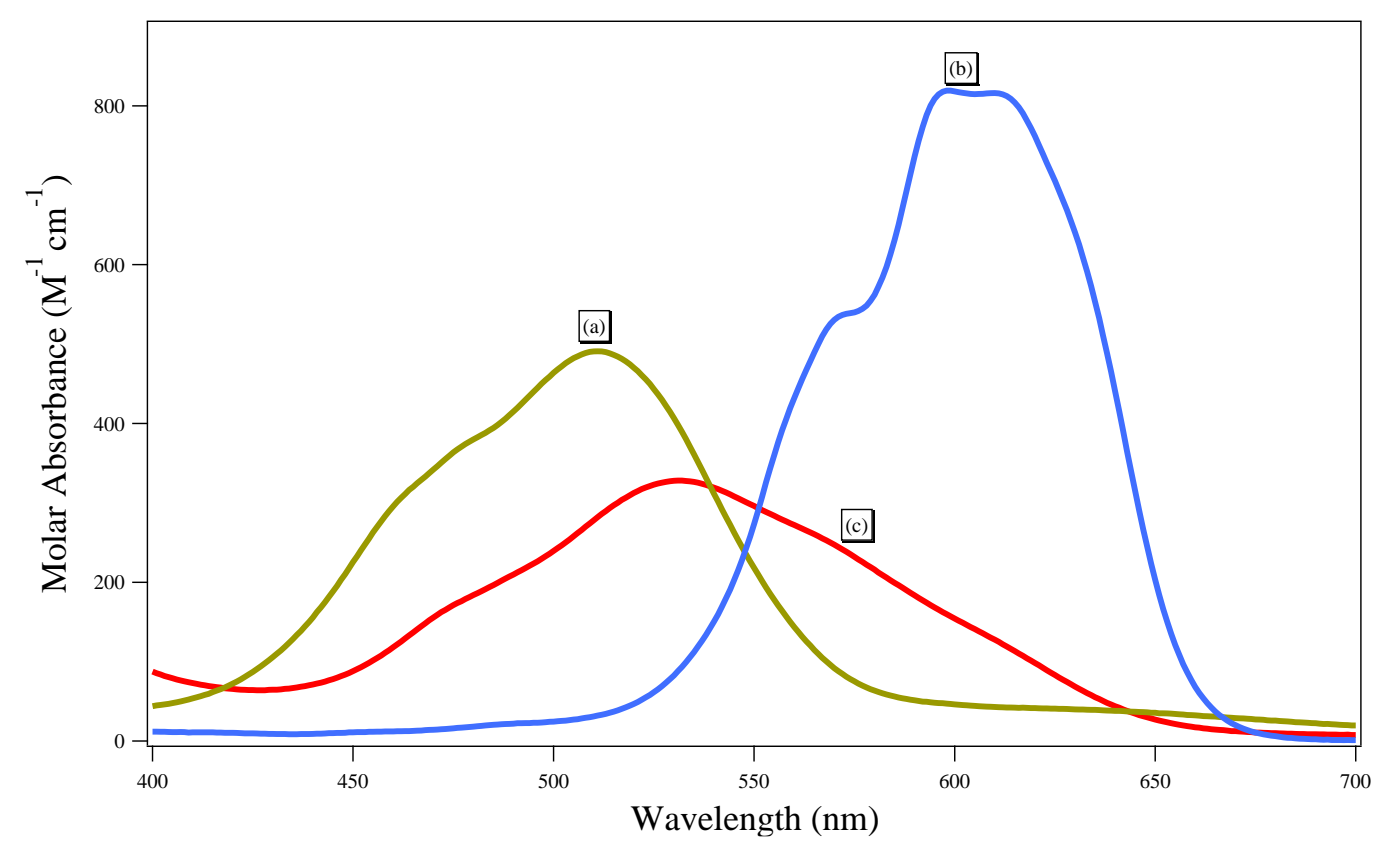

Figure 6. UV-Vis spectra of Co. $\left(\mathrm{NO}_{3}\right)_{2}$ in (a) $\mathrm{BuNC}_{2} \mathrm{OC}_{8}$-Dca phase; (b) aqueous phase step up 100 times and; (c) $\mathrm{BuNC}_{2} \mathrm{OC}_{8}$-ClSal phase step up 10 times. $\mathrm{C}_{\text {metal }}=0.05 \mathrm{~mol} \mathrm{~L}^{-1} ; \mathrm{V}_{\mathrm{w}}=2 \mathrm{~mL}$; $\mathrm{m}_{\mathrm{Il}}=0.5 \mathrm{~g} ; \mathrm{UV}$-vis spectra are recorded in ethylacetate for IL phase

In previous works, we pointed out the properties of tri(n-butyl)[2-ethoxy-2-oxoethyl]ammonium $\left(\mathrm{BuNC}_{2} \mathrm{OC}_{2}{ }^{+}\right)$dicyanamide (Dca) and bis(trifluoromethylsulfonyl)imide $\left(\mathrm{Tf}_{2} \mathrm{~N}^{-}\right)$ionic liquids with for the extraction of metal cations $[26,29,30] . \mathrm{Tf}_{2} \mathrm{~N}^{-}$is a non-coordinating anion currently used to generate ionic liquid. $\mathrm{BuNC}_{2} \mathrm{OC}_{2}$-Dca extracts quantitatively $\mathrm{Cu}$ (II), $\mathrm{Ni}(\mathrm{II}), \mathrm{Cd}$ (II) and $\mathrm{Pb}$ (II) from $0.05 \mathrm{~mol} \mathrm{~L}^{-1}$ aqueous solutions. By comparison, for the same metal concentration, $\mathrm{BuNC}_{2} \mathrm{OC}_{2}-\mathrm{Tf}_{2} \mathrm{~N}$ provides only weak extraction with extraction yield less than 10\% [30]. Similar observations have been made with ionic liquid based tetraalkylammonium cation associated with $\mathrm{Dca}^{-}$and $\mathrm{Tf}_{2} \mathrm{~N}^{-}$anions [29]. Although it has high extraction yields, $\mathrm{BuNC}_{2} \mathrm{OC}_{2}$-Dca does not allow considering applications in the field of the purification of industrial effluents because of its solubility in water $(\approx 6 \%)$, that is why we focused on the development of more hydrophobic ionic liquids, to reduce the releasing of organic cations in aqueous phase. The high extraction properties of $\mathrm{Dca}^{-}$based ionic liquids are ascribed to the ability of dicyanamide anion to interact with metallic cations through the formation of metal complexes via their nitrogen atoms [33,34]. The examination of the structure of metal complexes in which the dicyanamide anion acts as a ligand, shows that this anion behaves as a monodentate or bridging ligand [33,34]. It is reasonable to think that the higher extraction yields observed for $\mathrm{Cu}$ (II) and $\mathrm{Cd}$ (II) compared to those of $\mathrm{Ni}(\mathrm{II}), \mathrm{Co}$.(II) and $\mathrm{Pb}$ (II) are related to their higher affinity for $\mathrm{Dca}^{-}$anion, which favors their transfer from aqueous to ionic liquid phases. However, the lack of thermodynamic data from the literature does not allow corroborating this affirmation. The only published data show that the affinity of the dicyanamide ligand for $\mathrm{Cd}(\mathrm{II})$ ions is higher than for $\mathrm{Pb}$ (II) with a $\log \beta_{1}$ values of 3.11 for $\mathrm{Cd}$ (II) [39] against 2.1 for $\mathrm{Pb}$ (II) [40]. These values also show that the affinity of 
the dicyanamide ligand for the metal cations is lower than in the case of the chlorosalicylate ligand, which is consistent with the lower extraction yields observed with dicyanamide based ionic liquids compared to the chlorosalicylate one. The dicyanamide based ionic liquids are equally less selective for the first row transition metals than their analogous with $\mathrm{ClSal}$ anions. The selectivity factors $\mathrm{SF}(\mathrm{Cu} / \mathrm{Ni})$ and $\mathrm{SF}\left(\mathrm{Cu} / \mathrm{Co}\right.$.) are equal to 8 and 10.6 for $\mathrm{BuNC}_{2} \mathrm{OC}_{4}$-Dca and with $\mathrm{BuNC}_{2} \mathrm{OC}_{8}-\mathrm{Dca}_{\text {, }}$ $\mathrm{SF}(\mathrm{Cu} / \mathrm{Co}$.) is equal to 4.29 . The main exception is the relatively high selectivity of $\mathrm{Cu}(\mathrm{II})$ towards $\mathrm{Ni}$ (II) with $\mathrm{BuNC}_{2} \mathrm{OC}_{8}$-Dca, compared to other systems, with a selectivity factor of 53 due to a low percentage of $\mathrm{Ni}$ (II) extracted. It is to be noticed the low affinity of dicyanamide based ionic liquids for $\mathrm{Pb}$ (II) ions which makes it possible to use them effectively to separate metals from $\mathrm{Pb}$ (II) ions. With $\mathrm{BuNC}_{2} \mathrm{OC}_{8}$-Dca, the selectivity factors $\mathrm{SF}(\mathrm{Cu} / \mathrm{Pb})$ and $\mathrm{SF}(\mathrm{Cd} / \mathrm{Pb})$ are equal to 230 and 170.

The UV spectrum of $\mathrm{Ni}(\mathrm{II})$ in $\mathrm{BuNC}_{2} \mathrm{OC}_{8}$-Dca exhibit the same features as the spectrum of $\mathrm{Ni}\left(\mathrm{H}_{2} \mathrm{O}\right)_{6}{ }^{2+}$ in aqueous solution, and is characteristic to $\mathrm{Ni}(\mathrm{II})$ in an octahedral environment. The shift towards weaker energies indicates a change in the nature of donor atoms bound to the metal center related to the implication of nitrogen atoms in the coordination sphere of the metal [38].

The UV-visible spectrum of $\mathrm{Cu}$ (II) in $\mathrm{BuNC}_{2} \mathrm{OC}_{8}$-Dca show the same features as in $\mathrm{BuNC}_{2} \mathrm{OC}_{8}-\mathrm{ClSal}$ in the visible region, except that the shift of the $\mathrm{d}-\mathrm{d}$ transition is less marked than with $\mathrm{BuNC}_{2} \mathrm{OC}_{8}-\mathrm{ClSal}$ with a maximum at $780 \mathrm{~nm}$. In the UV region, the spectrum shows a supplementary transition centered at $390 \mathrm{~nm}$ (not shown here). This transition is ascribed to an LMCT (or MLCT) transition characteristic of the Dca coordination to $\mathrm{Cu}$ (II) cation. The spectrum of Co.(II) in $\mathrm{BuNC}_{2} \mathrm{OC}_{4}\left(\mathrm{C}_{8}\right)$-dca shows in the visible region a band at $600 \mathrm{~nm}$ with a shoulder at $570 \mathrm{~nm}$. The molar absorption coefficient at $600 \mathrm{~nm}$ is equal to $810 \mathrm{~cm} \mathrm{~mol}^{-1} 1$. The spectral features of Co(II) spectra in Dca ionic liquids are characteristic of a $\mathrm{Co}(\mathrm{II})$ in tetrahedral environment, meaning a change of coordination of the metal during the extraction process. The band is assigned to a $A_{2}(F) \rightarrow T_{1}(P)$ transition [38].

The saccharinate anion behaves as monodentate ligand through its nitrogen atom or as a bidentate through N,O coordination [41]. It often act as a ternary ligand in structure of many metal complexes to achieve the coordination of metal ions [42]. No data are available in the literature concerning the formation constants in aqueous solution of divalent metal complexes with this anion, suggesting a weak coordinating ability in aqueous phase towards metal ions. One key point is that saccharin ionic liquids have a high affinity only for $\mathrm{Cd}(\mathrm{II})$, and may also be efficient to separate cadmium from other divalent cations. Indeed, the lowest selectivity factors for cadmium towards other divalent cations $\left(\mathrm{SF}_{(\mathrm{Cd} / \mathrm{M})}=\mathrm{D}(\mathrm{Cd}(\mathrm{II})) / \mathrm{D}(\mathrm{M}(\mathrm{II}))\right)$ is that with $\mathrm{Cu}(\mathrm{II})$ ions. They are equal to 63 and 80 for $\mathrm{BuNC}_{2} \mathrm{OC}_{8}-\mathrm{SaC}$ and $\mathrm{BuNC}_{2} \mathrm{OC}_{4}$-Sac, respectively.

\subsection{Influence of the Cation of the Ionic Liquid}

Figure 3 shows that the cation of the ionic liquid has a significant influence on the extraction of metal cation. Indeed, the extraction yield is significantly higher with $\mathrm{BuNC}_{2} \mathrm{OC}_{4}^{+}$than with $\mathrm{BuNC}_{2} \mathrm{OC}_{8}{ }^{+}$cations. This trend is related to (i) the more hydrophilic character of the tetrahexylammonium cation which may favor the transfer of the metal in the ionic liquid phase via cationic exchange process, and (ii) the fact that the concentration of anion, in the ionic liquid phase, is higher in $\mathrm{BuNC}_{2} \mathrm{OC}_{4}{ }^{+}$ILs than with $\mathrm{BuNC}_{2} \mathrm{OC}_{8}{ }^{+}$ILs. Indeed, as an example taking into account the molar mass of $\mathrm{BuNC}_{2} \mathrm{OC}_{4}$-Dca and $\mathrm{BuNC}_{2} \mathrm{OC}_{8}$-Dca, the mole number contacted with the aqueous phase in an extraction sample is respectively of $1.3 \mathrm{mmol}$ for $\mathrm{BuNC}_{2} \mathrm{OC}_{4}$-Dca and $1.1 \mathrm{mmol}$ for $\mathrm{BuNC}_{2} \mathrm{OC}_{8}$-Dca, respectively. Such a difference may be taken into account to explain partially the better extraction properties of $\mathrm{BuNC}_{2} \mathrm{OC}_{4}$-Dca, which contains a higher concentration of extractant. To investigate if ion exchange occurs during extraction, coextraction of nitrate ion was followed by ion-chromatography. When a cation exchange occurs, the metal ion in the aqueous phase is exchanged 
with a cation of the ionic liquid. The metal ion is then extracted into the ionic liquid, while the cation of the IL moves to the aqueous phase following the equilibria:

$$
\mathrm{M}^{2+}{ }_{(\mathrm{w})}+2 \mathrm{BuNC}_{2} \mathrm{OC}_{\mathrm{n}}{ }_{(\mathrm{IL})}^{+}+\mathrm{nA}^{-}{ }_{(\mathrm{IL})} \rightleftharpoons \mathrm{M}(\mathrm{A})_{\mathrm{n}}{ }^{(\mathrm{n}-2)-}{ }_{(\mathrm{IL})}+2 \mathrm{BuNC}_{2} \mathrm{OC}_{\mathrm{n}}{ }^{+}{ }_{(\mathrm{w})}
$$

If extraction proceeds only via ion-pairing, the counter anion of the metal salt is co-extracted into the ionic liquid phase, so that the ratio between the metal and the counter-ion extracted should be equal to one considering the following equilibria:

$$
\mathrm{M}^{2+}{ }_{(\mathrm{w})}+2 \mathrm{X}^{-}{ }_{(\mathrm{w})}+\mathrm{nA}^{-}{ }_{(\mathrm{IL})} \rightleftharpoons \mathrm{M}(\mathrm{A})_{\mathrm{n}}{ }^{(\mathrm{n}-2)-}{ }_{(\mathrm{IL})}+2 \mathrm{X}^{-}{ }_{(\mathrm{IL})}
$$

The determination of the co-extraction rates of nitrate ion gives an indirect insight of the amount of cation released in the aqueous phase and allow to investigate the extraction mechanism of metal cation. Figure 7 depicts the ratio $R$ between the extraction rate of nitrate ion and those of metal.

Ion-pairing is the dominant mechanism with $\mathrm{BuNC}_{2} \mathrm{OC}_{8}{ }^{+}$cation. Indeed, for all systems, except for $\mathrm{Cu}(\mathrm{II}) / \mathrm{BuNC}_{2} \mathrm{OC}_{8}-\mathrm{ClSal}$, the ratio $\mathrm{E}\left(\mathrm{A}^{-}\right) / \mathrm{E}\left(\mathrm{C}^{+}\right)$values are close and even may exceed 1 (Figure 7). A value higher than 1 means that the anions of the metal salt are more efficiently extracted than metal itself and suggests the possibility of anion exchange between the anion of the ionic liquid and the nitrate ions. This may take place during the extraction of Co.(II) in $\mathrm{BuNC}_{2} \mathrm{OC}_{8}$-Dca $(\mathrm{R}=1.3)$ and to a small extent with $\mathrm{BuNC}_{2} \mathrm{OC}_{8}$-ClSal $(\mathrm{R}=1.1)$.

The $\mathrm{R}$ value is much less than one with $\mathrm{BuNC}_{2} \mathrm{OC}_{4}{ }^{+}$cation, meaning that the mechanism for extracting metal ions is a mixed process that includes both cation exchange and ion-pair extraction. The $\mathrm{R}$ value represents the extent of ion-pair extraction. It is clearly seeing from Figure 7 that with $\mathrm{BuNC}_{2} \mathrm{OC}_{4}$-Clsal, the extraction of metal proceeds mostly via cation-exchange, especially, in the case of the extraction of $\mathrm{Ni}(\mathrm{II})$. In the case of $\mathrm{BuNC}_{2} \mathrm{OC}_{4}-\mathrm{Dca}$, the two mechanisms are operant, nearly to the same extent.

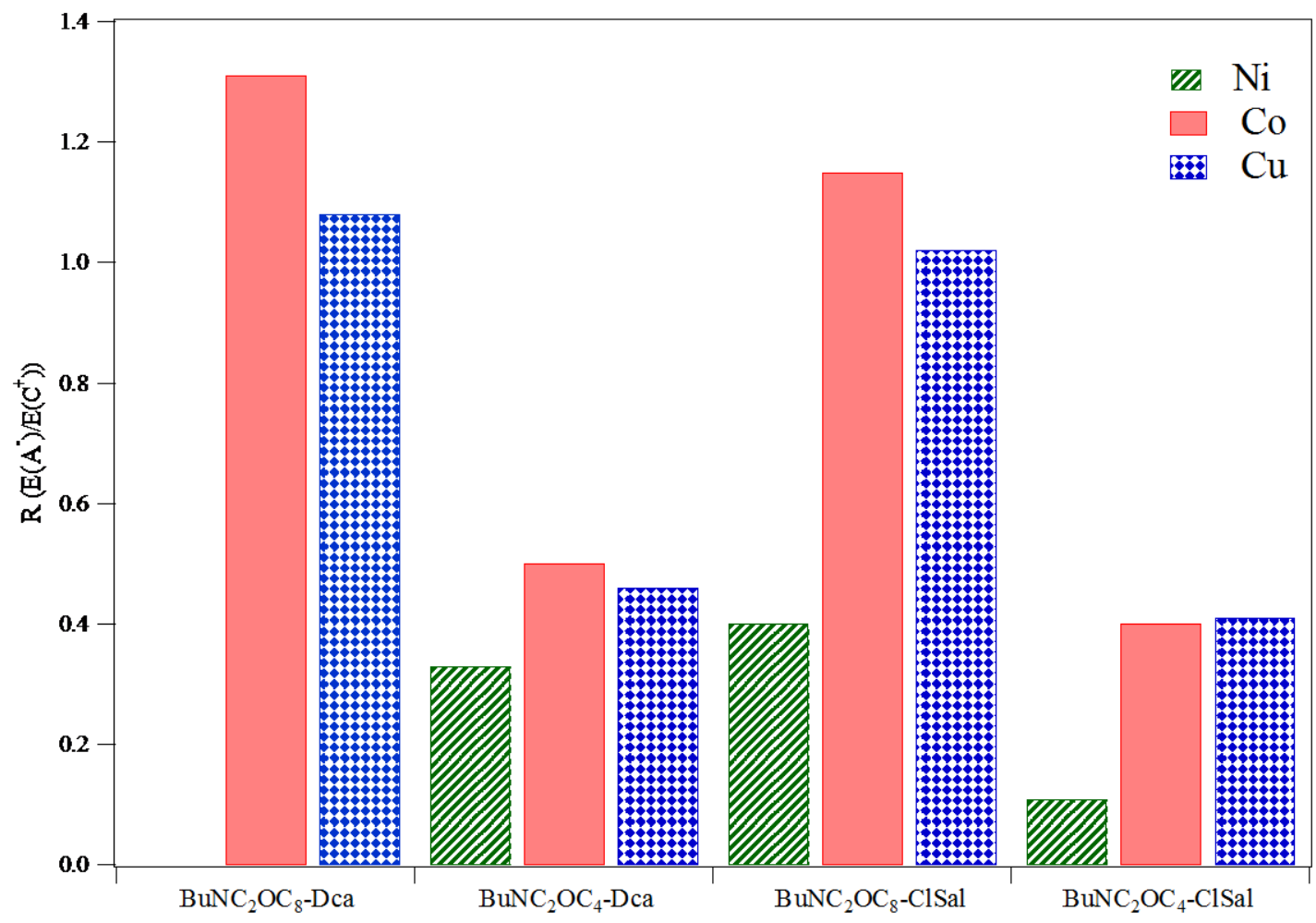

Figure 7. Ratio $\left(\mathrm{A}^{-} / \mathrm{C}^{+}\right)$between the extraction rate of anion and those of $\mathrm{Cu}(\mathrm{II}), \mathrm{Co}$.(II) and $\mathrm{Ni}(\mathrm{II})$, for the different salt used at different concentration. 
All the results show that $\mathrm{BuNC}_{2} \mathrm{OC}_{4}{ }^{+}$based ionic liquids are more efficient to extract metal ions than that of $\mathrm{BuNC}_{2} \mathrm{OC}_{8}{ }^{+}$. The disadvantage is that their higher solubility leads to the extraction with a large proportion of cationic exchange resulting in a significant release of organic cations in the aqueous phase. In comparison, $\mathrm{BuNC}_{2} \mathrm{OC}_{8}{ }^{+}$based ionic liquids, despite their lower performance, favor exclusively ion-pair extraction and allow the development of more eco-compatible extraction processes. These results may suggest that the $\mathrm{BuNC}_{2} \mathrm{OC}_{4}{ }^{+}$based ionic liquids would be less viable in large-scale use. However, it is also necessary to conceive a possible use in media with high salinities, which corresponds to most liquid industrial effluents. As we have shown in previous work [26], high salinity causes an increase in extraction efficiency, promotes ion pair extraction and thus limits the release of organic cations during extraction processes.

\subsection{Back-Extraction of Metal Ions and Recyclability of Ionic Liquid}

The back-extraction process will be based on exchange ligand reaction and would be suitable by using a hydrophilic ligand with stronger affinity for metal cations than the anions of ionic liquid. To verify this hypothesis, we carried out the experience of back-extraction with aqueous disodique EDTA solution at $0.1 \mathrm{~mol} \mathrm{~L}^{-1}$ contacted with ionic liquid phases previously loaded with metal. EDTA is a hexavalent ligand that forms stable 1:1 complexes with divalent metals; the stability constants of the complexes formed are often higher than 12 (in logarithmic units). In this case, the back-extraction process would involve a replacement of $\mathrm{M}(\mathrm{II})$ by $\mathrm{Na}^{+}$ions in the ionic liquid phase, or the back-extraction of $\mathrm{NO}_{3}{ }^{-}$ions previously extracted in the ionic liquid phase, or both of them.

Figure 8 shows that EDTA is an efficient ligand to recover metal ions from the ionic liquid phase. $\mathrm{Cu}(\mathrm{II})$ is back extracted from $\mathrm{BuNC}_{2} \mathrm{OC}_{\mathrm{n}}-\mathrm{Clsal}$ with recovery percentages close to $100 \%$ and higher than $80 \%$ with $\mathrm{BuNC}_{2} \mathrm{OC}_{\mathrm{n}}$-Dca. The efficiency is observed for the recovery of $\mathrm{Ni}$ (II) $\mathrm{Cd}$ (II) and Co.(II) from these two ionic liquids. $\mathrm{Cd}(\mathrm{II})$ is also fully back extracted from $\mathrm{BuNC}_{2} \mathrm{OC}_{\mathrm{n}}-\mathrm{Sac}$ with a back extraction percentage exceeding $90 \%$.

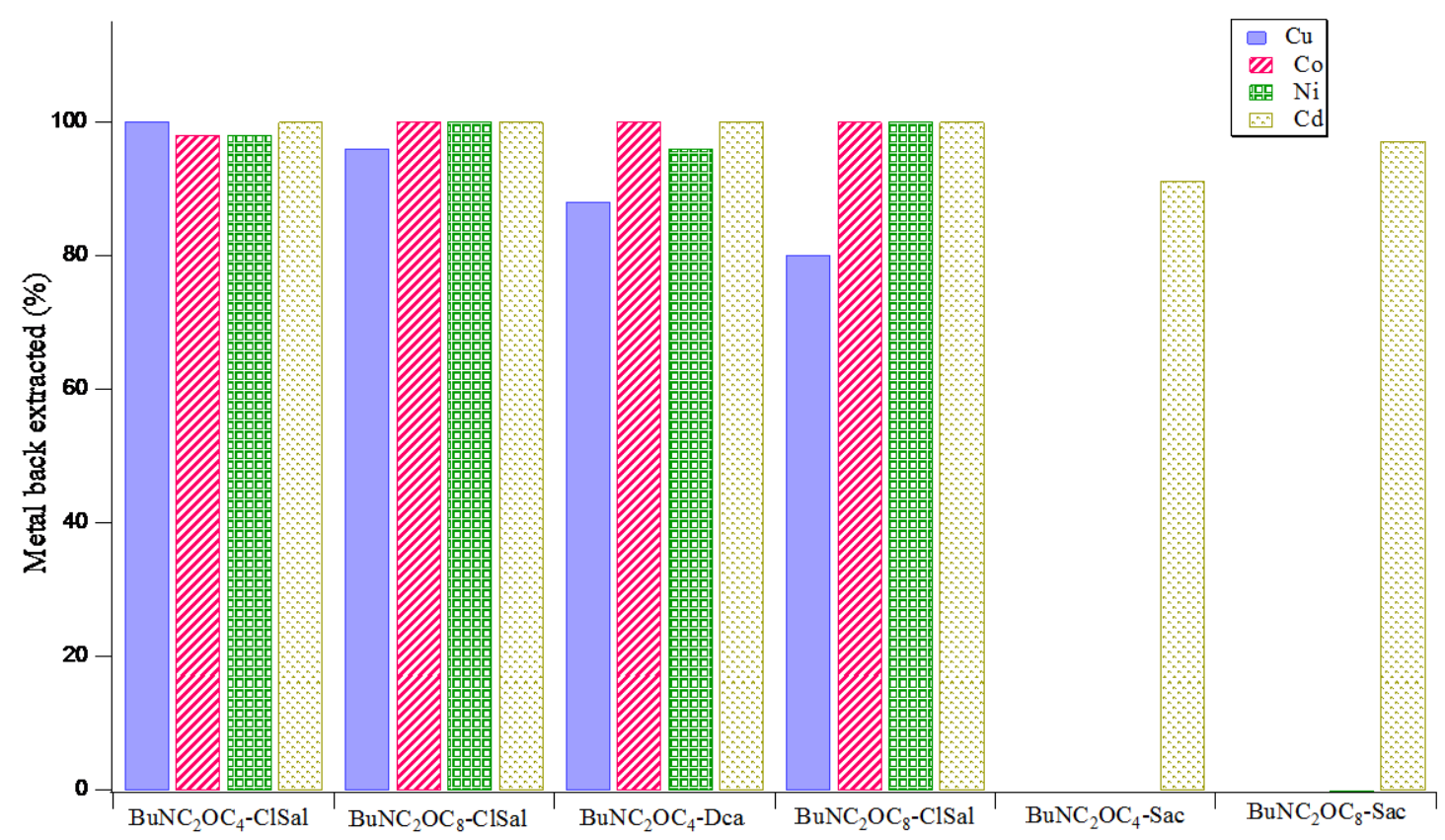

Figure 8. Extraction and back-extraction yield (\%E) for M(II).

After the back-extraction process, it is important to check if the ionic liquid would be able to be reused for the extraction of metal from aqueous solution. To check the recyclability of the ionic 
liquids, several cycles of extraction-back extraction were carried-out on the same ionic liquid phase, following the same experimental conditions as those reported previously.

After each cycle, the metal concentration was determined in the aqueous phase, and the extraction and back-extraction yields have been determined by taking into account the total concentration of metal present in the ionic liquid phase. Figure 9 reports the extraction and back-extraction yields for $\mathrm{Cu}$ (II) and $\mathrm{Co}$.(II) with $\mathrm{BuNC}_{2} \mathrm{OC}_{\mathrm{n}}$-Sal ionic liquid.

The results show that the efficiency of extraction and back-extraction remained similar over three cycles. The extraction yields are nearly constant over the three cycles, whereas the back-extraction yields are higher than $95 \%$. Therefore, these results confirm that the ionic liquid can be regenerated in the back-extraction process with EDTA solution and can be reused for metal extraction; the release of ionic liquid remains sufficiently limited to not alter the performance of the latter. These results may be generalized for all the systems studied in this work.

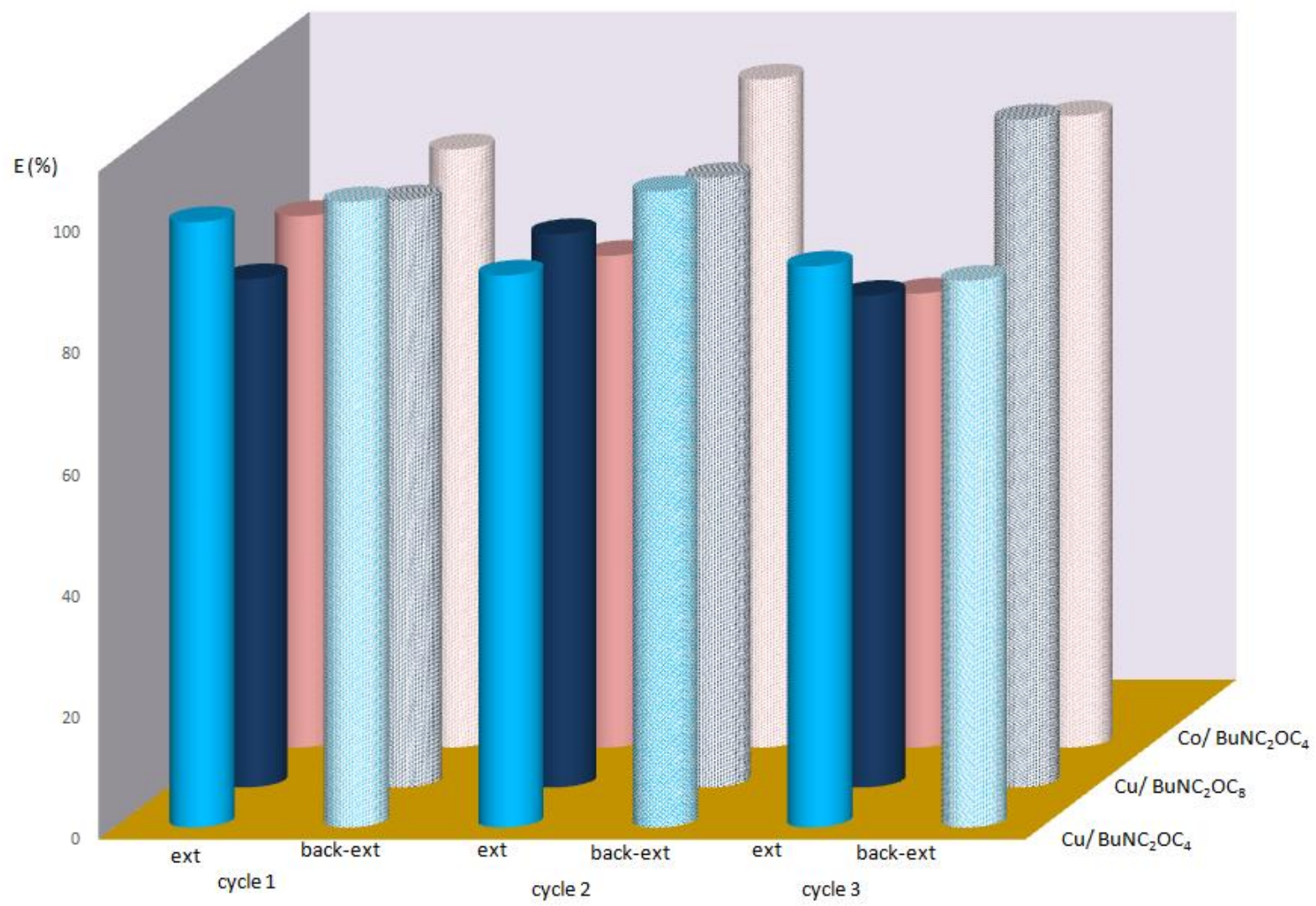

Figure 9. Reusability of ionic liquid phase for copper and cobalt extraction using $\mathrm{BuNC}_{2} \mathrm{OC}_{\mathrm{n}}-\mathrm{Clsal}_{\text {. }}$

\section{Conclusions}

Our results report the possibility of designing in a simple way hydrophobic ILs able to extract efficiently metallic cations by liquid-liquid extraction. The ionic liquids use as negative pole common coordinating anions, such as dicyanamide, chlrorosalicylate and saccharinate, instead of fluorinated compounds. Our first results show that chlorosalicylate based ionic liquids have a high extraction efficiency towards $\mathrm{Cu}(\mathrm{II}), \mathrm{Ni}(\mathrm{II}), \mathrm{Cd}(\mathrm{II})$, and $\mathrm{Pb}(\mathrm{II})$, whereas dicyanmide based ionic liquids may extract efficiently $\mathrm{Cu}(\mathrm{II})$ and $\mathrm{Cd}(\mathrm{II})$. Ionic liquids with saccharinate anions are selective of $\mathrm{Cd}(\mathrm{II})$ ions. The UV-vis investigations of the first row transition metals show the coordination of the metal with the anion of ionic liquids.

The extraction process is reversible with all the ionic liquids, and the metal ions can be recovered by aqueous solutions of disodique EDTA. In order to conceive environmentally-friendly systems for 
industrial applications, a workable way is to privilege the ionic liquids with the $\mathrm{BuNC}_{2} \mathrm{OC}_{8}{ }^{+}$cation, which are less soluble. The ionic liquids with the $\mathrm{BuNC}_{2} \mathrm{OC}_{4}{ }^{+}$cation nevertheless remain interesting for the development of liquid-liquid extraction processes, but their extraction properties must be studied in higher salinity environments which favor extraction by ion pair. These results show that the strategy of designing ionic liquids with coordinating anions with low hapticity giving moderately stable complexes in the ionic liquid phase is a promising route for the extraction of aqueous metal ions. In this case, the metals can be easily recovered in the aqueous phase with water-soluble ligands with high hapticity.

Author Contributions: L.D. and S.B. designed the detailed experimental plan for this research. P.D.D. carried out the experiments and data analysis under the supervision of S.B and A.M., L.D. and A.M. wrote the manuscript with help of other coauthors.

Acknowledgments: The authors are grateful to the "Region Grand Est" and the FEDER for a Grant to Pape Diaba Diabate and for its financial support.

Conflicts of Interest: The authors declare no conflict of interest.

\section{References}

1. Lichtfouse, E.; Schwarzbauer, J.; Rober, T.D. Environmental Chemistry: Green Chemistry and Pollutants in Ecosystems; Springer: Berlin, Germany, 2005; p. 780.

2. Kumbasar, R.A. Extraction and concentration study of cadmium from zinc plant leach solutions by emulsion liquid membrane using trioctylamine as extractant. Hydrometallurgy 2009, 95, 290-296. [CrossRef]

3. Blais, J.F.; Dufresne, S.; Mercier, G. State of the art of technologies for metal removal from industrial effluents. Revues Des. Sci. De L'eau 1999, 12, 687-711. [CrossRef]

4. Fu, F.; Wang, Q. Removal of heavy metal ions from wastewaters: A review. J. Environ. Manag. 2011, 92, 407-418. [CrossRef] [PubMed]

5. Huddleston, G.J.; Willauer, H.D.; Swatloski, R.P.; Visser, A.E.; Rogers, R.D. Room temperature ionic liquids as novel media for "clean" liquid-liquid extraction. Chem. Commun. 1998, 1765-1766. [CrossRef]

6. Zhao, H.; Malhotra, S.V. Applications of ionic liquids in organic synthesis. Aldrichimica Acta 2002, 35, 75-83. [CrossRef]

7. De los Rios, A.P.; Hernandez-Fernandez, F.J.; Lozano, L.J.; Sanchez, S.; Moreno, J.I.; Godinez, C. Removal of metal ions from aqueous solutions by extraction with ionic liquids. J. Chem. Eng. Data 2010, 55, 605-608. [CrossRef]

8. Papaiconomou, N.; Lee, J.M.; Salminen, J.; Von Stosch, M.; Prausnitz, J.M. Selective extraction of copper, mercury, silver, and palladium ions from water using hydrophobic ionic liquids. Ind. Eng. Chem. Res. 2008, 47, 5080-5086. [CrossRef]

9. Zhao, H.; Xia, S.; Ma, P. Use of ionic liquids as 'green' solvents for extractions. J. Chem. Technol. Biotechnol. 2005, 80, 1089-1096. [CrossRef]

10. Reyna Gonzales, J.M.; Torriero, A.A.; Siriwardana, A.I.; Burgar, I.M.; Bond, A.M. Extraction of copper(II) ions from aqueous solutions with a methimazole-based ionic liquid. Anal. Chem. 2010, 82, 7691-7698. [CrossRef] [PubMed]

11. Germani, R.; Mancini, M.V.; Savelli, G.; Spreti, N. Mercury extraction by ionic liquids: Temperature and alkyl chain length effect. Tetrahedron Lett. 2007, 48, 1767-1769. [CrossRef]

12. Kidani, K.; Hirayama, N.; Imura, H. Extraction behavior of divalent metal cations in ionic liquid chelate extraction systems using 1-alkyl-3-methylimidazolium bis(trifluoromethanesulfonyl)imides and thenoyltrifluoroacetone. Anal. Sci. 2008, 24, 1251-1254. [CrossRef] [PubMed]

13. Egorov, V.; Djigailo, D.I.; Momotenko, D.S.; Chernyshow, D.V.; Torochesnikova, I.I.; Smirnova, S.V.; Pletner, I.V. Task-specific ionic liquid trioctylmethylammonium salicylate as extraction solvent fortransition metal ions. Talanta 2010, 80, 1177-1182. [CrossRef] [PubMed]

14. Lertlapwasin, R.N.; Bhawawet, N.A.; Imyin, A.S.; Fuangswasdi, S. Ionic liquid extraction of heavy metal ions by 2-aminothiophenol in 1-butyl-3-methylimidazolium hexafluorophosphate and their association constants. Sep. Purif. Technol. 2010, 72, 70-76. [CrossRef] 
15. Holbrey, J.D.; Visser, A.E.; Spear, S.K.; Reichert, W.M.; Swatloski, R.P.; Roger, R.D. Mercury(II) partitioning from aqueous solutions with a new, hydrophilic ethylene-glycol functionalized bis(methylimidazolium) ionic liquid. Green Chem. 2003, 5, 129-135. [CrossRef]

16. Visser, A.E.; Swatloski, R.P.; Reichert, W.M.; Mayton, R.; Sheff, S.; Wierzbicki, A.; Davis, J.H., Jr; Rogers, R.D. Task-specific ionic liquids for the extraction of metal ions from aqueous solutions. Chem. Commun. 2001, 135-136. [CrossRef]

17. Visser, A.E.; Swatloski, R.P.; Reichert, W.M.; Mayton, R.; Sheff, S.; Wierzbicki, A.; Davis, J.H., Jr.; Rogers, R.D. Task-specific ionic liquids incorporating novel cations for the coordination and extraction of $\mathrm{Hg}^{2+}$ and $\mathrm{Cd}^{2+}$ : Synthesis, characterization, and extraction studies. Environ. Sci. Technol. 2002, 36, 2523-2529. [CrossRef] [PubMed]

18. Harjani, J.R.; Friscic, T.; MacGillivray, L.R.; Singer, R.D. Removal of metal ions from aqueous solutions using chelating task specific ionic liquids. Dalton Trans. 2008, 34, 4595-4601. [CrossRef]

19. Olivier, J.H.; Camerel, F.; Selb, J.; Retailleau, P.; Ziessel, R. Terpyridine-functionalized imidazolium ionic liquids. Chem. Commun. 2009, 1133-1135. [CrossRef] [PubMed]

20. Jensen, M.P.; Neuefeind, J.; Beitz, J.V.; Skanthakumar, S.; Soderholm, L. Mechanisms of metal ion transfer into room-temperature ionic liquids: The role of anion exchange. J. Am. Chem. Soc. 2003, 125, 15466-15473. [CrossRef] [PubMed]

21. Mehdi, H.; Binnemans, K.; Van Hecke, K.; Van Meervelt, L.; Nockemann, P. Hydrophobic ionic liquids with strongly coordinating anions. Chem. Commun. 2010, 46, 234-236. [CrossRef] [PubMed]

22. Jensen, M.P.; Dzielawa, J.A.; Rickert, P.; Dietz, M.L. EXAFS Investigations of the mechanism of facilitated ion transfer into a room temperature ionic liquid. J. Am. Chem. Soc. 2002, 124, 10664-10665. [CrossRef] [PubMed]

23. Dietz, M.L.; Dzielawa, J.A. Ion-exchange as a mode of cation transfer into room-temperature ionic liquids containing crown ethers: Implications for the 'greenness' of ionic liquids as diluents in liquid-liquid extraction. Chem. Commun. 2001, 2124-2125. [CrossRef]

24. Dietz, M.L.; Dzielawa, J.A.; Laszak, I.; Young, B.A.; Jensen, M.P. Influence of solvent structural variations on the mechanism of facilitated ion transfer into room-temperature ionic liquids. Green Chem. 2003, 6, 682-685. [CrossRef]

25. Dietz, M.L.; Stepinski, D.C. A ternary mechanism for the facilitated transfer of metal ions into room-temperature ionic liquids (RTILs): Implications for the "greenness" of RTILs as extraction solvent. Green Chem. 2005, 7, 747-750. [CrossRef]

26. Messadi, A.; Mohamadou, A.; Boudesocque, S.; Dupont, L.; Guillon, E. Task-specific ionic liquid with coordinating anion for heavy metal ion extraction: Cation exchange versus ion-pair extraction. Sep. Purif. Technol. 2013, 107, 172-178. [CrossRef]

27. Root, A.; Binnemans, K. Efficient separation of transition metals from rare earths by an undiluted phosphonium thiocyanate ionic liquid. Phys. Chem. Chem. Phys. 2016, 18, 16039-16045. [CrossRef] [PubMed]

28. Parmentier, D.; Van der Hoogerstraete, T.; Banerjee, D.; Valia, Y.A.; Metz S, J.; Binnemans, K.; Kroon, M.C. A mechanism for solvent extraction of first row transition metals from chloride media with the ionic liquid tetraoctylammonium oleate. Dalton Trans. 2016, 45, 9661-9668. [CrossRef] [PubMed]

29. Khalil, M.; Radalla, A. Binary and ternary complexes of inosine. Talanta 1998, 46, 53-61. [CrossRef]

30. Baran, E.J. The saccharinate anion: A versatile and fascinating ligand in coordination chemistry. Quim. Nova 2005, 28, 326-328. [CrossRef]

31. Martın, S.; Gotzone Barandika, S.M.; Ruiz de Larramendi, J.L.; Corte, R.; Font-Bardia, M.; Lezama, L.; Serrna, Z.E.; Solans, X. Structural analysis and magnetic properties of the 1D and 3D compounds, [Mn(dca)2nbipym] $(\mathrm{M}=\mathrm{Mn}, \mathrm{Cu}$; dca = Dicyanamide; bipym = Bipyrimidine; $n=1,2)$. Inorg. Chem. 2001, 40, 3687-3692.

32. Mohamadou, A.; Van Albada, G.A.; Kooijman, H.; Wieczorek, B.; Spek, A.L.; Reedijk, J. The binding mode of the ambidentate ligand dicyanamide to transition metal ions can be tuned by bisimidazoline ligands with H-bonding donor property at the rear side of the ligand. N. J. Chem. 2003, 27, 983-988. [CrossRef]

33. Boudesocque, S.; Mohamadou, A.; Martinez, A.; Déchamps, I.; Dupont, L. Use of dicyanamide ionic liquids for metal ions extraction. RSC Adv. 2016, 6, 107894-107904. [CrossRef] 
34. Zhou, Y.; Boudesocque, S.; Mohamadou, A.; Dupont, L. Extraction of metal ions with Task-specific ionic liquids : Influence of a coordinating anion extraction. Sep. Sci. Technol. 2015, 50, 38-44. [CrossRef]

35. De Gaetano, Y.; Mohamadou, A.; Boudesocque, S.; Hubert, J.; Plantier-Royon, R.; Dupont, L. Ionic liquids derived from esters of Glycine Betaine: Synthesis and characterization. J. Mol. Liq. 2016, 207, 60-66. [CrossRef]

36. Powell, K.J. SC Query SC-database, data version 4.44, soft version 5.346.

37. Mimoun, M.; Pointud, Y.; Juillard, J.; Juillard, J. Interactions in methanol of divalent metal cations with bacterial iono-phores, lasalocid and monensin-Thermodynamical aspects. Bull. Soc. Chim. Fr. 1994, 131, 13158-13165.

38. Lever, A.B.P. Inorganic Electronic Spectroscopy, 2nd ed.; Elsevier: New York, NY, USA, 1986.

39. Skopenko, V.V.; Samoilenko, V.M.; Movchan, O.G. Study of cadmium halide and pseudohalide complexes in dimethylacetamide. Zh. Neorg. Khim. 1981, 26, 1319-1323.

40. Skopenko, V.V.; Samoilenko, V.M.; Garbous, S. Potentiometric study of lead halide and pseudohalide complexes in dimethylacetamide. Zh. Neorg. Khim. 1982, 27, 665-668.

41. Valle-Bourrouet, G.; Pineda L, W.; Falvello L, R.; Lusar, R.; Weyhermueller, T. Synthesis, structure and spectroscopic characterization of $\mathrm{Ni}(\mathrm{II}), \mathrm{Co}(\mathrm{II}), \mathrm{Cu}(\mathrm{II})$ and $\mathrm{Zn}(\mathrm{II})$ complexes with saccharinate and pyrazole. Polyhedron 2007, 26, 4440-4478. [CrossRef]

42. Ali, M.A.; Mirza, A.H.; Ting, W.Y.; Hamid, M.H.S.A.; Bernhardt, P.V.; Butcher, R.J. Mixed-ligand nickel(II) and copper(II) complexes of tridentate ONS and NNS ligands derived from S-alkyldithiocarbazates with the saccharinate ion as a co-ligand. Polyhedron 2012, 48, 167-173. [CrossRef]

(C) 2018 by the authors. Licensee MDPI, Basel, Switzerland. This article is an open access article distributed under the terms and conditions of the Creative Commons Attribution (CC BY) license (http:// creativecommons.org/licenses/by/4.0/). 